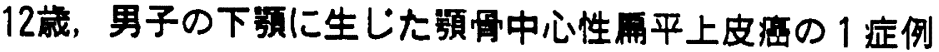

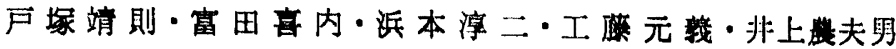

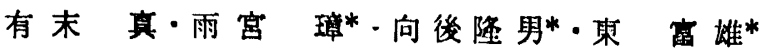

\section{Central squamous cell carcinoma of the mandible in child aged 12: Report of a case}

\author{
Yasunori Totsuka - Kinai Tomita - Junji Hamamoto - Motonori Kudō - Nobuo Inoue
}

Makoto Arisue - Akira Amemiya* - Takao Kohgo* • Tomio Azuma*

粕

훔

悪性隀福，なかであ癌腫は中・高榆者に好発する疾患 て，小児に生ずることは比較的まれなるのである。平 山゙の報告によれば昭和49年の全虚死亡数 133,751 に対

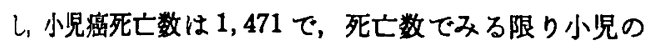

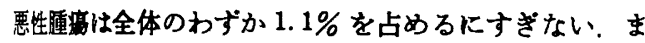
た小児覀性新生物全国登録2)によれば昭和49年の登録数 壮1,000 例で，このらち口腔領域に生じたるのはわずか

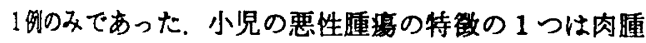
の類度の高いことであるが，口腔領域に生ずる場合も同 槏に肉盾の頻度が高いとされ，癌腫症例の報告はきわめ て少ない，われわれが涉橅し得た限りでは本邦より 5 咧，諸外国より15例の計20例が報告されているにすぎな かった.

われわれは12歳，男子の下影に生じた扁平上皮癌を経 的した。本症例は臨床的, 病理組織学的に顎骨中心性に 発生したものと考えられ，また齿原性上皮由来を示唆す 万所見を示した．われわれはこのよらなきわめてまれな 症例を程験したので，その概要を報告するととすに，そ の由来上皮に関して若干の考察を試みた。 また，䫓・口 䜿領域に生した小呪癌について文献的考察を行ったので あわせて報告する。

北海道大学歯学部第 1 口腔外科学教室（主任：富 田喜内救授）

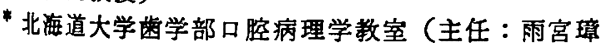
数授)

Department of Oral Surgery 1, School of Dentistry, Hokkaido University (Chief: Prof. Kinai Tomita)

* Department of Oral Pathology, School of Dentistry, Hokkaido University (Chief: Prof. Akira Amemiya)

受付日：昭和54年 8 月 20 日
症例

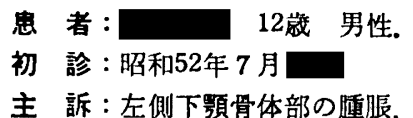

主 部: 左側下額骨体部的重服。

家族歴および既往歷：特記事項はない，

現病歴：当科初診の約 1 年前, 左侧下影齿肉煩移行部

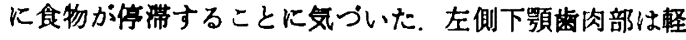
度に発赤・尰脹し，また軽度の圧痛が虫められたか，自 発痛を欠き全身的にも巽常が琶められないため放置して いた，その後，症状が改善しないため，炤和52年 3 月， 某柬科医を受診し口内炎の衫断にて的 2 か月間，同部の 洗浄を受けていた，昭和52年 6 月中旬，左側下䫟骨体部 の腫脹に気づき，さらにその数日後，左影下リンバ節の 腫大か認められたため，他の歯科医を受診した，X線検 查により|厉万胞性歯寒胞と診断され，精查と治療の目 的で当科を紹介され，昭和52年 7 月—受診した，なお， 初発より当科初診までの間, 発熱, 倦急感, 食欲不振な どは認められていない。 また厉 に関しては明らかな 記憶かなく，自然脱落したものと思われた，

現 症：体格はやや小柄であるか，発育・栄酸はとも に中等度で，また全身所見には特記事項はない。

頋貌所見：顔色良好で，眼瞼結膜に負血はない，顔貌 は非対称で, 左側下影骨体部に骨棣硬, びまん性の膨隆 が認められる. 同部の皮庙ははは正常であるが，左側才 トガイ領域に軽度の知覚低下が認められる（写真 1)。 左額下部に小指頭大, 弾性硬, 可動性, 無痛性のリンハ 節 1 個，また左右額下部に，米粒大より小豆大までの大 きさの, 弾性軟, 可動性, 無痛性のリンパ節を数個触知 するが，頙部リンパ節は触知されない.

口腔内所見: 開口度 $48 \mathrm{~mm}$ で開口制限なく, 下顎運 動にも異常は認められない.|1部より左側臼後三角部 にわたる㧘槽突起部に，表面やや不整で軽度の圧痛を伴 5 , 弾性硬の腫脹が梕められる(写直 2，3）. 被覆粘膜 は一部暗赤色を呈し，また部分的に斑状の色素沈着がみ 


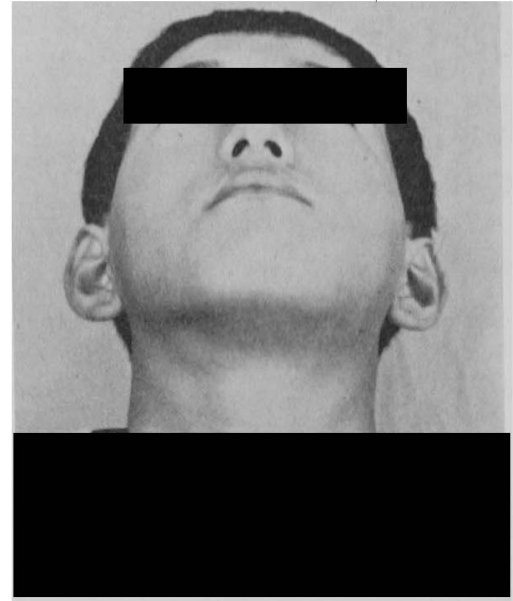

军真 1 初診特颜貌所見

左側下顎部にびまん性の骨踣㦀が琶められる。

られる・厉はわずかに遠心傾斜し，また厉部粘膜には

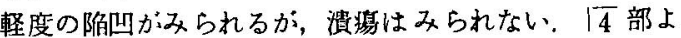
り後方の崡肉頓移行部に浅い陌山がみられ，問围に軽度 の硬結が触知される。只底, 舌, 前口䔔弓部には異常 は認められない、庶，何はともに失活して皮り，軽度 の動播がみられる。 $\overline{8}[578$ は未萌出である。

X線所見：| 5 相当骨体部に中央に埋伏米を有する類 円形の透過像が認められる。原 の齿根膜腔は軽度に払 大して扣り，また同部荬慒骨にわずかながら骨硬化像が 認められるが，明らかな骨破壤像は瑟められない（写苸 4).

胸部X線所見には特記事項はない、

臨床検查所見：アルカリ性フォスファターセ值29.7単 位と軽度上昇を認める以外は，すべて正常範囲内である (表 1 ).

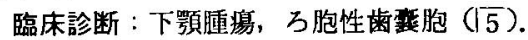

処 置：崡槽突起部抽よひ煩粘膜硬結部より採取した 組織片は，病理組織学的に癌腫と診断されたため，左䫛 下リンパ節の試験切除を行った，病理組織学的喻索の結 果, 同リンパ節への転移が確認され，病理組織学的に 扁平上皮癌と診断された。昭和 52 年 7 月几入院し， Betatron にて，2,500 rads/10 回の術前照射を行った。

9 月—, 全身麻酔下にて左側全頸部廓清術, 下額連続 離断術および腫煌摘出術を施行した。下顎は $\overline{3}$ 部およ び左側上行枝部で切断し，骨欠損部は 1 次的にチタニウ ム板にて架橋した，口腔粘膜は硬結部より最小限 $10 \mathrm{~mm}$ の健康部を含んで切除し，創は 1 次的に稀合閉鎖した。

摘出物の肉眼的所見およびX線所見 : $\overline{3}$ 部および下

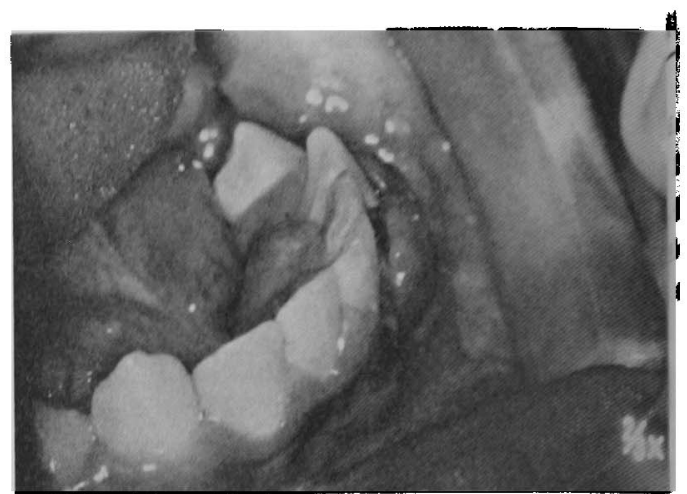

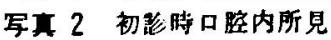

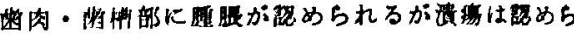
れない

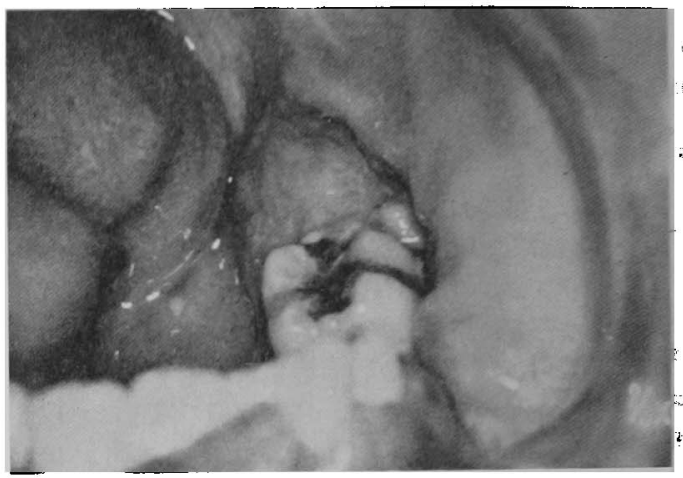

写真 3 同上

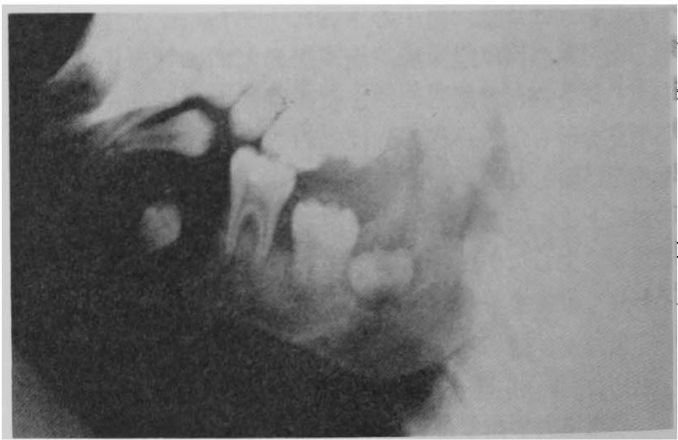

写高 4 初喰時X線所見

中央に埋伏齿可を有する境界の明らかな類円形 透過像が認められる。また，原部菌槽骨に軽度の 骨硬化像が認められる。

顎上行枝部の骨切断面は健康で，また軟組絨切開部にる

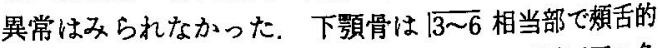
に，びまん性に膨隆していた，顎下部，顠静脈周用に多 数のリンパ節が認められたが，いずれる弾性軟で，周囲 
表 1 初喰時踀床检查成根

\begin{tabular}{|c|c|c|c|}
\hline \multicolumn{2}{|l|}{ 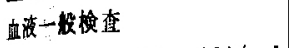 } & ALP & 28. $2 \mathrm{U}$ \\
\hline 赤血球数 & $451 \times 10^{4} / \mathrm{m} l$ & GOT & $35 \mathrm{U}$ \\
\hline 血色素量 & $12.6 \mathrm{~g} / \mathrm{d} l$ & GPT & $25 \mathrm{U}$ \\
\hline ヘントクタ & ッ值 $39 \%$ & LDH & $305 \mathrm{U}$ \\
\hline 血小板数 & $19.5 \times 10^{4} / \mathrm{d} l$ & BUN & $12.6 \mathrm{mg} / \mathrm{d} l$ \\
\hline 白血球数 & $4,600 / \mathrm{d} l$ & 電解䨘 & \\
\hline Eos. & $1.5 \%$ & $\mathrm{Na}$ & $142 \mathrm{mEq} / l$ \\
\hline Baso. & 0 & $\mathbf{K}$ & $4.6 \mathrm{mEq} / l$ \\
\hline Mon. & $3.0 \%$ & Cl & $104 \mathrm{mEq} / \mathrm{l}$ \\
\hline Seg. & $49.0^{\circ}{ }_{0}$ & C'a & $9.6 \mathrm{mg} / \mathrm{d} l$ \\
\hline St. & $2.5^{\circ} 0$ & 無機燐 & $3.5 \mathrm{mg} / \mathrm{d} l$ \\
\hline Lympho. & $44.0 \%$ & その他の㑯代 & \\
\hline 生化学检查 & & W氏反応 & $(-)$ \\
\hline 蛋白 & $8.2 \%$ & 伥䨞白 & $(-)$ \\
\hline ZTT & $3.6 \mathrm{KU}$ & 尿 館 & $(-)$ \\
\hline TTT & $0.1 \mathrm{KU}$ & CRP & 0 \\
\hline 淧ビリルピ & ソ $0.6 \mathrm{mg} / \mathrm{d} l$ & ASLO & $160 \mathrm{U}$ \\
\hline コレステ & $\begin{array}{l}=-ル \\
169 \mathrm{mg} / \mathrm{d} l\end{array}$ & $\gamma-\mathrm{gl}$. & $19.4 \%$ \\
\hline Ch-E & $0.71 \Delta \mathrm{pH}$ & & \\
\hline
\end{tabular}

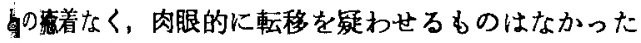
(写真5). Softex による摘出物の X線所見は，初钐時 のX線所見とはば同様であったが，垂直方向の撮影像に 蛇いて厉部の煩側骨皮質に放射状の骨新生像が認めら れた，毒胞様骨透過像を示した部分の骨皮質は，煩舌的 にかなり瞦隆希薄化していたが，連続性で骨欠損を示す 所見淂られなかった（写真 7，8）.

\section{病理組敉学的所見 :}

生模摽本（曾肉および歯模粘膜）; 粘膜上皮下に，部 位により多少異なる増殖形態を示す癌組織がみられた。

一报飞明瞕な核小体と均質な核質を有する，円形ないし 快那円形の大きな核をむつ腫瘍細胞が比較的充実性に增 道していた（写真 9)。細胞質は淡明なものが多く, 角化 の碩向にはこしいが，一部では好酸性の境界明瞙な細胞 筫を有するすのあみられた，核分裂像ははとんど認めら れなかった，間質には多数の好酸球を含も著明な炎症性

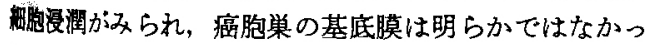
た，このような部位に近接して，明瞭な梀をるち，角化 の值向を示す重瘍細胞よりなる多数の小さな類円形増殖 果るるられたまた一部に2,3 列の，類円形の濃染する 药々好酸性の胞体を有する腫瘍細胞よりなる短い索状の 增集るみられたが，胞巣の一部は太さを増し，表皮様 是していた。このよらな部位では，比較的緻密な線維 生組瀻よりなるかなり多量の間質がみられた（写真10).

一般に被覆上皮の基底膜は明瞭であったが，一部で董瘍 との境界が不解明な部位るみられた。

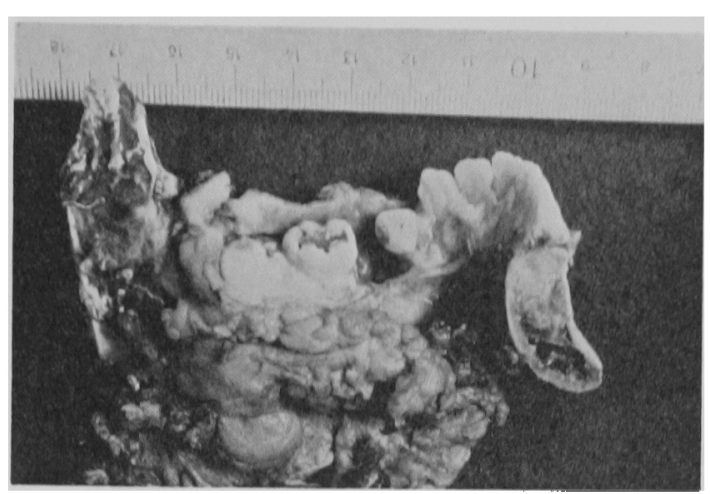

写五 5 摘出物所見

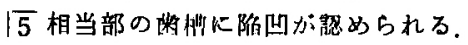

生検摽本（影下リンパ節）；リンパ節は充実性に增殖 した癌組䄉ではとんど直さ换えられ，リンパ組絨は周辺 部にわずかに認められるにすぎなかった，腄㗄然質は $1 ， 2$ 個の明膫な核小体と網状に分布する核質をるち， 円形、㽗円形あるいは多角形で，異型性の著明な核を有 する細胞よりなっていた。一般に細胞質は少なく不整形 で，角化の傾向はほとんど諗められなかったが，ところ どころに，境界明膫な好酸性の胞体をるち，わずかなか ら角化の傾向を示す縕胞むみられた，核分裂像は泣と儿

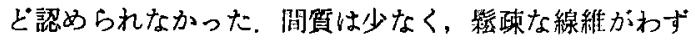
かに認められる程度であったが，多数の好酸球を含む著 明な細胞浸潤が諗められた（写真11）。た一部には壊 死然もみられた。

摘出物標本；埋伏雪（可）を中心に近遠心的には $\sqrt{4}$ から原邀心部に及ぶはほ球状の骨吸収がみられ， 菌冠を包さよらに癌組織が珰められた（写真12），骨吸 収は著明で，下縁部では骨皮質ははとんど認められなか った｜可は，根尖部で煩側への屈曲を示していたか， それ以外は形態はほぼ正常で，また崡髄腔への病の浸潤 は認められなかった、可のエナィル・セメント境から エナメル質の外形に一致する形で 1,2 層の退縮エナメ ル上皮がみられたか，これは舌側咬頭部で陥凹している 口羫粘膜上皮と瘾合し，連続性を示していた。この部の 退樎エナメル上皮は肥厚し, 扁平上皮様を星していた。

歯頸部には太い膠原線維が束をなして付着し，外側に向 かって放射状に配列しており，癌組織は主としてこの線 維束より画冠側に認められた。

| 5 歯冠上部に最著明な癌の浸潤が双られた（写直 12～14）.この部では，一般に末分化な異型性の強い腫 演細胞が比較的びまん性の増殖を示していた。このよう な胞巣は角化の傾向に乏しかったが，一部は表皮様で， 大きな好酸性胞体を有する細胞るみられた，間質内には リンパ球，形質細胞，好中球また部位によってはかなり 多数の好酸球の浸潤がみられた。一部には褐色色素を貝 


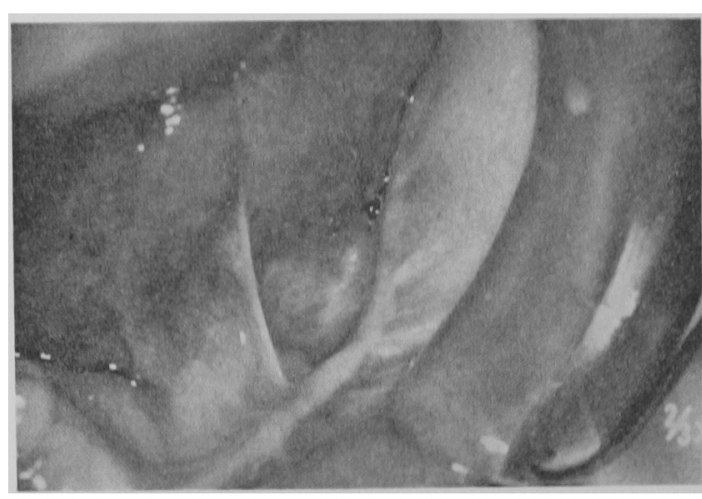

写真 6 手优媵 1 年 7 か月維遇時の几腔内所胃

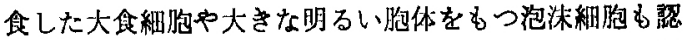
められた，その他の部位では膸演実貿は比校的小さな類 円形の胞染を形成していた，癌細胞は明陸な核小体を们 する大型の核と好酸性胞体を有する細胞で，その一部は 明膫な橉をるち，また癌真珠状を呈していた（写真14）. 核の大小不同はみられたが，㤥分裂像はほとんど認めら れなかった，間質は軣な線維性組織よりなり，好酸球を 含む炎症性細胞浸潤が著明で，胞晕の基底膜は不鮮明で あったなな和このよらな部位では，腫场細胞は一部変性 傾向を示し，多核巨細胞による会食像も認められた，癌 胞栄の一部は退縮エナメル上皮ときわめて近接していた か，連続する像は明らかではなかった（写直12，15）。 頓側の粘嗼上皮は薄く，その一部は宿勾部を被㠅してい たが，底部付近では上皮は欠如して批り肉芽組織および 癌組織か露出していた，舌侧の粘膜上皮はやや厚かった

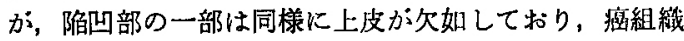
が露出していた（写真12）.

雪槽粘膜上皮下にす癌胞巣は認められたが，小唾液㟫 への癌細胞の浸潤はみられなかった，癌細胞は，主とし て小さな胞巣を作って浸潤し，その浸潤範囲は市いから $\sqrt{7}$ 遠心側に及んでいた（写真16）。原舌側婵肉部には 比較的未分化な充実性の胞巣がみられた。 $\mid \overline{7}$ 遠心根部 では歯根膜内にも癌胞巣が認められた。原部顎骨, 特 に下縁部拉よび頓側部に外骨膜性の著明な骨新生がみら れ，この新生骨梁間にも癌胞巣が認められた（写真17). $\mid \overline{7}$ 冠の䫅側上方に歯牙様硬組織の小塊が存在し，そ れに近接して齿原性石灰化上皮腫を思わせる上皮の增殖 巣がみられたが，異型性などの悪性像はなく，周辺に存 在する癌胞巣との直接の関係は認められなかった（写直 18).

顎下リンバ節および頸部リン八節には転移巣は認めら れなかった。

経 過: 手術後の経過は良好であったが, 術後 2 か月 目に顎下部に褯瘡性潰湯を生じチタニウム板の露出がる られたただちにチタニウム板を除去し，創は一次的に

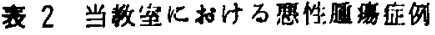

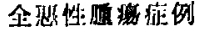

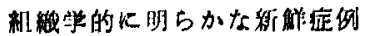

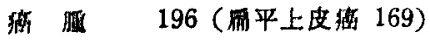

肉 㬴 25

小先恐吽胍㨉

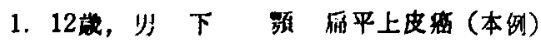

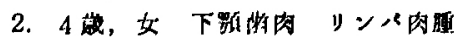

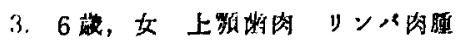

(北大口外：S42.8〜S52.7)

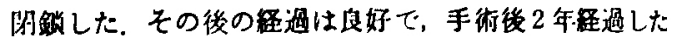
现在，局所再発あるいは浣隔枟移の徽候もみられず健在 である，また下類および影部の運䖝制限し認められない (写直 6 ).

\section{考察}

小児の要性連瘍は単に頻度か：低いといらばかりでな

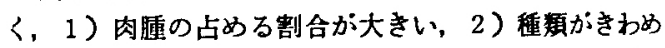
て多い，3）胎見生組織より生ずるるがあるなど, 成人に生ずる悪性腫场とはかなりの相違がみられ，ま

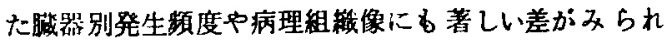
$ろ^{1-32}$ ．さらに悪性度が高い，主訴・症状が理解しがた い，成長期に発生するなど，診断・治療の面でる成人の 場合とは異なった困矆性を有している゙．

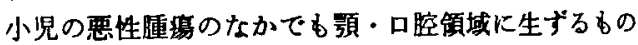
はきわめて少ないか，そのなかでは一般に肉腫の頻度が

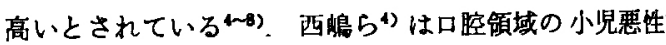
腄湟13例中，癌腫はわずか1例(粘表皮癌)であったと報

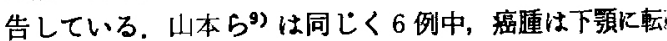
移した Wilms 腫湯 1 例のみであったと報告している. われわれの症例です，昭和 42 年 8 月より昭和 52 年 7 月ま での10年間江报った小児悪性腫疸 3 例中, 癌睡は本症例 1 例のみで他の 2 例は悪性リンパ腫症例であった（表 2). 頭・ 口腔領域原発の小少癌腫症例の報告はきわ的 て少ないが，岡ら ${ }^{10} は 7$ 嵗女子の崡肉癌症例を報告し， あわせて内外文献より得られた16例の原発性小罗口院癌 尰症例を検討している5,11 19)，われわれはさらに3例の 追加症例 4 20,21) を涉椫し得たので，本症例を加えた21例 について検討した（表了〜 5)。これによれば原発性小 児口腔癌腫はいずれの年跉層にあ発生しらるものである か，他部位の小児悪性腫瘍が 5 歳以下の幼児に好発する のに比べ1，，5歳以上の年長児に好発する㑯向がるられ る. 男女比は 2 対 1 で男児に好発して扰り，成人の口腔 癌腫症例と同様の結果である ${ }^{222}$. 発生部位は, 舌 7 例, 下顎 6 例と両者で過半数を占めるが，その他，口唇，口

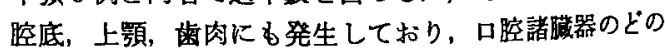




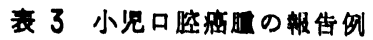

\begin{tabular}{|c|c|c|c|c|c|c|c|c|}
\hline 坛告者（年次 & & 部 位 & 䖽 類 & 年桷 & 性 & 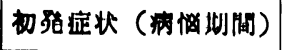 & 治 & 予 传 \\
\hline 1 Frank, 他* & (1936) & 舌 & 网平上皮雷 & 2 週 & 男 & & 不 甽 & 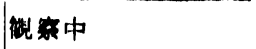 \\
\hline 2 Saleeby* & $(1940)$ & 舌 & 扁平上皮蛇 & 15 㿫 & 女 & 不 明 & 不 明 & 死 (10か月) \\
\hline 3 New, 他* & $(1940)$ & 舌 & 同平上皮艘 & 13鼔 & 男 & 不 明 & 不 明 & 不 明 \\
\hline 4 New, 他* & $(1940)$ & 下ロ厔 & 届平上皮跒 & 13宸 & 男 & 不 明 & 不 明 & 不 明 \\
\hline 5 Aisenberg & (1942) & 下類 & 舟 & 9 党 & 男 & 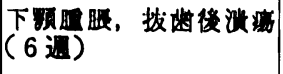 & 手 微 & 不 明 \\
\hline 6 Campelia & (1943) & 下領 & 未分化癌 & 9 殿 & 男 & 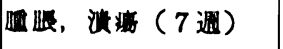 & 手 衙 & 微案中（再発あり） \\
\hline 7 Kapiloff & (1952) & 下口辰 & 稨平上皮如 & 6 か月 & 男 & 国笛形成（6週） & 手 赫 & 嗂来中 \\
\hline 8 Dowd & (1954) & 上額肉 & 网平上皮狂 & 10绕 & 男 & 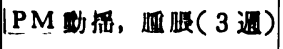 & 乎 你 & 鯢案中（6か月） \\
\hline 9 Merrifield, 他 & (1955) & 舌・运 & 雨平上皮酒 & 4 减 & 女 & 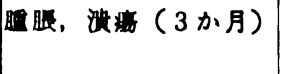 & 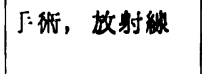 & 死（4か月） \\
\hline Stiebitz & (1963) & 下影 & 末分化舟 & 15 詼 & 男 & $\mid \overline{8}$ 部且脤 & 厂婌, 化学法 & 死（4か月） \\
\hline 1 Jones & (1966) & 下预 & 未分化践 & 4 鹿 & 女 & $|\overline{43}|$ 变位, 目脹 & 手政，放射線 & 䘽察中（1 年） \\
\hline 12 Marsden, 他* & (1968) & 口腔底 & 扁平上皮私 & 3 悕 & 男 & 不 明 & 不 明 & 不 明 \\
\hline 3 上野 & (1969) & 上预因肉 & 末分化蛙 & 7 旅 & 男 & 不 明 & 不 明 & 死 \\
\hline 4 太田 & (1969) & 呫 & 扁平上皮癌 & 7 殿 & 男 & 不 明 & 不 明 & 死 \\
\hline 15 Lancaster, 他 & (1969) & 活 & 扁平上皮跑 & 6 叞 & 男 & 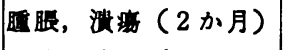 & 放射線 & 死（9か月） \\
\hline 6 Turner, 他 & (1974) & 舌 & 扁平上皮粮 & 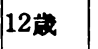 & 男 & 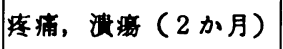 & 放射線, 手很 & 死 (11か月) \\
\hline 西鹃，他 & (1974) & 上口辰 & 粘表皮㾔 & 14宸 & 女 & 不 明 & 不 明 & 不 明 \\
\hline 18 Caldwell, 他 & (1974) & 上頻洞 & 末分化癌 & 8 减 & 女 & 通脹（10日） & 手御, 化学法 & 死（10か月） \\
\hline 19 作田, 他 & (1975) & 上䫑 & 末分化菑 & 3 か月 & 女 & 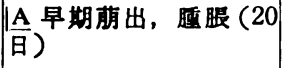 & 化学法 (中断) & 䚁寀中 ( 3 年 3 か月) \\
\hline ( & (1975) & 下額畨肉 & 扁平上皮漹 & 7 葴 & 女 & 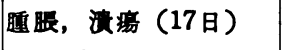 & 手 御 & 覵察中( 2 年 6 か月) \\
\hline 本例 & (1979) & 下影 & 扁平上皮船 & 12歳 & 男 & 尰脹（1 年） & 放射線，手很 & 䅐察中（ 2 年） \\
\hline
\end{tabular}

*女献10）より転裁

表 4 小坚口腔癌尰の病理組践別および性別発生頻 度

\begin{tabular}{|c|c|c|c|}
\hline 扁平上皮瘦 & 13例 (62\%) & 男 & 14例 \\
\hline 末分化舟 & 6例 $(29 \%)$ & 女 & 7例 \\
\hline 粘表皮峦 & 1例 & \multirow{3}{*}{\multicolumn{2}{|c|}{$(2: 1)$}} \\
\hline 瘦 & 1例 & & \\
\hline 計 & 21 例 & & \\
\hline
\end{tabular}

部位からであ発生しらるよらである。なお下影に生じた 6 例中 5 例は顥骨中心性に生じたもので，成人の下䫓癌 の大多数が粘膜癌であるのに比べ，著しい相違がみられ た，5例とす崡原性由来とされ，また本症例を除く 4 例 は未分化癌ないしは単に癌と診断されており, 発癌の問 道上興味ある点之思われる. 初発症状は無痛性腫脹が大 多数で，また潰瘍を伴らすのが多かった，予後に関して 性過制察中 8 例，死亡 8 例，予後不明 5 例であるが， 十分な经過钼察期間を有する症例は少なく予後はさらに 覀いるのと推定される. 小児癌は診断, 治療および悪性

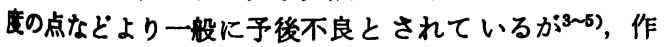

表 5 小䇺悪性尰瘦の年龄別頻度

\begin{tabular}{|c|c|c|c|c|}
\hline 年龄（剑） & $0 \sim 1$ & $1 \sim 4$ & $5 \sim 9$ & $10 \sim 15$ \\
\hline 小児悪性盾瘍死亡数 ${ }^{1)}$ & 107 & 584 & 430 & 350 \\
\hline 小児口腔痁 & 3 & 3 & 7 & 8 \\
\hline
\end{tabular}

田ら21)は十分な治療を行い得なかったにもかかわらず腫 場の消失をみた興味ある 1 例を報告し，自然退縮したる のであろらと推論している. 塙名) 新生児期においては 隀湯の自然寬解をみることがあると述べている.

本症例は臨床的・病理組織学的に靧骨内より発生 し た，いわゆる䅡骨中心性癌の所見を示した．影骨の瘦腫 は, 一般に口腔粘膜ないしは額骨周囲組織に生した癌尰 の䅡骨漫潤によるものが多いとされ23,24)，また靧骨中心 性に発生したと考えられる場合です，他領域に生じた原 発巣よりの転移巣であることが多いとされ24)，䫓骨中心 性癌と診断する場合, これらの可能性が否定されなけれ ばならない，本症例は下頽齿肉部の腫脹を初発症状とし ていたが，初診時口腔粘膜に潰晹は認められず，また下 顥骨体部の腫脹に比べ, 歯肉部の腫脹は軽度であった。 


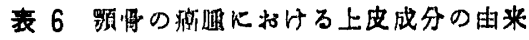

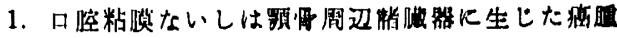

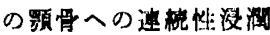

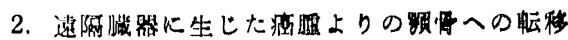

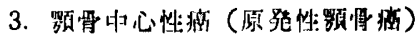

1) 米原性:上皮

a 、楼是の残㟟上皮

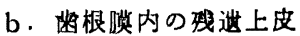

c . 退粳エナメル上皮

d. 堤上皮・阫上皮成分

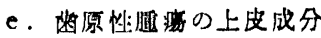

f. 性重胞の上皮成分

2 ）胎生期の楮突起骼合部の牫造上皮

3) 䫑骨内迷入上皮（胎生期上皮，血液腺上皮， 粘液腺上皮等）

X線所見でも下顎骨体部に，中央に埋伏画 ( $\overline{5})$ を有す る円形の变胞様透過像が認められたのみで，因肉尰服部 に一致した歯槽突起部に明らかな吸収破壊像は認められ なかった，病理組織学的にも腫瘍の大部分は下䫛骨骨髄 内に存在していた，摘出物標本の一部に氡上皮を欠き 陣瘍の露出している部分が認められたか，これは組織片 採取による二次的なるのと考えられる。また雪肉上皮と 退縮エナメル上皮とが密接に関係している部分がみられ

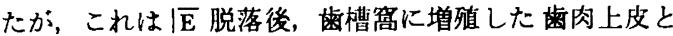
退縮エナメル上皮とが二次的に接触愈合したものと考元 られる，同部の退縮エナメル上皮は軽度の肥厚を示して いたか，異型性は認められなかった。

本症例が転移症例である可能性については，治療前後 の全身精査および現在までの経過上，原発巣と考えられ る隀瘍が認められていないこと，口腔転移癌は一般に腺 癌が多いこと 25), さらに後述することとく病理組織学的に 崡原性由来を示唆する所見が得られていることなどか ら，その可能性は少ないと考えられる.

䫇骨中心性癌における上皮性細胞の由来については, 一般に, 雪是の残遗上皮, 婳模内の残遺上皮, 退絔工 ナメル上皮, 胎生期の諸突起融合部に残存した上皮およ び顎骨内胞の上皮成分などが考えられている 26 32)，その他，歯原性腫湟の上皮成分 ${ }^{33}$ ，顎骨内に迷 入した胎生期上皮ないしは腺上皮などからも発生しらる むのとされている てまれなるのであるが，そのなかでは顎骨内凖胞の上皮 成分より生じたとする報告が多い3741)，Eversole ら は顠骨中心性に生じた扁平上皮癌症例36例および粘表皮

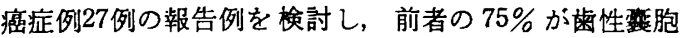
とまた後者の $48 \%$ が歯性蓄胞ないしは埋伏歯と関係し ていたと報告している。その他の報告でも歯性京胞との 関係を強調しているものが多いが，他方 Morrison 526)

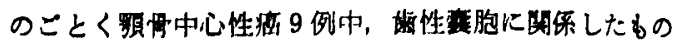
はわナ゙か 3 例であったとする椵告むみられる，本症例は

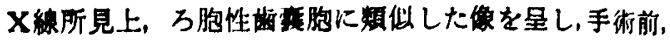

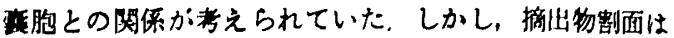

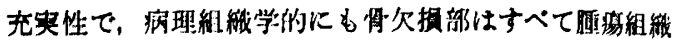

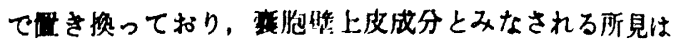
得られなかった。さらに可梅冠の外形に一致して退維 エナィル上皮が存在ナることから，原に淔接関速した ろ胞性齿落胞に由来したといら可能性は少ないと考えら れる、Nolan ${ }^{29)}$ によれば莫胞以外の影骨内上皮成分よ り発生した碩骨中心性症においても，級徐な発育を示す

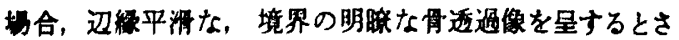
れ，本症例はこれに相当するるのと考えられる。

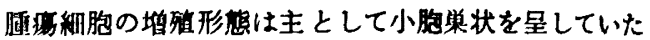
が,一部には索状の增殖も認められた，腫㷅細胞の增殖・ 浸洞の主体は埋伏可齿冠周囲に㑇められ，そのなかて も退縮エナメル上皮に近接する部に特に著明であった。 またこの部の腫湯細胞は比䡈的末分化で，買型性が弦 く，比較的びまん性の增殖形態を示しており，これらの 所見は腫掝細胞と退縮エナメル上皮との密接な関俰を示 唆するものと考えられる. 前述した小児口院癌睡症例 中，靧骨中心性に生じたとされている症例は4 例で，い ずれる崡原性由来とされている，Aisenberg'1) は著明な 骨新生を伴う症例を報告し，発生部位および稙瑒細胞の 増殖形態より齿原性由来が示唆されると述べ malignant adamantoblastoma と命名している. Campelia ${ }^{12)} は \sqrt{7}$ の早期萌出および骨随の厇籍な破壊を示す应例を報告 し，睡鹪細胞が末分化なことより齿原性上皮に由来した embryogenic carcinoma であろらと推論している.

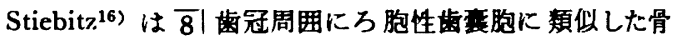

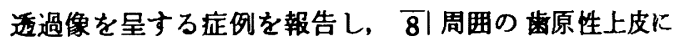
過形成および小衰胞形成が認められることより同上皮由

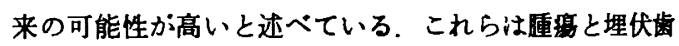

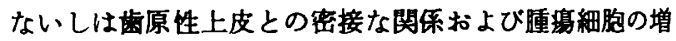
殖形態などより雪原性由来と考えられているるのである

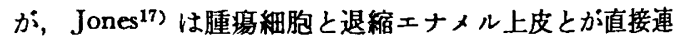
続性を示す症例を報告し，エナメル上皮腫の malignant variant であろうと述べている，本应例は前述したごと

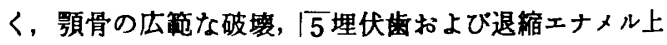
皮との密接な関係，腫腺細胞の多形性および小胞巣状増 殖が認められたことなどより齿原性上皮，そのなかです 退樎エナメル上皮より由来した可能性が高いと考えられ た。しかしながら腫㳻細胞と僈縮エナメル上皮との間 に，明らかな連続性は認められておらず，畽瘍の浸潤部 位より歯堤の残遺上皮より生じた可能性も否定できな

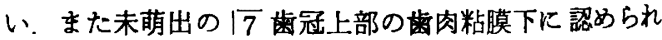
た粚原性石灰化上皮尰を思わせる像は，本腫瘍との直接 的な関係は明らかではないか，本症例の歯原性組織の異 常を示唆する所見と考えられる。 
揞出物骨傎下に明らかな放射状の新生骨が视められた か, Aisenberg ${ }^{11)}$, Campelia ${ }^{12)}$ 。同棣の所見を思めてお

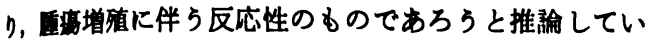
ろ.一般に成人の下額癌症例では認められないことよ り，成長期の小児に生ずる悪性腫畹に特徽的な所見と考 えられる。

\section{結㗉}

1.12歲，男子の下預に，額骨中心性に生じた扁平上 皮素の1例について報告した。

2. 本症例は臨床的所見およびX線所見より，手術前，

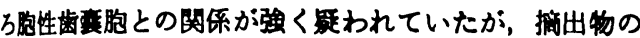

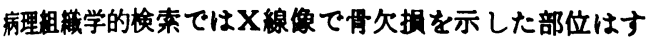

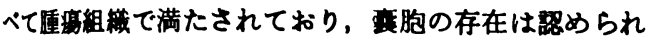
斿た。

3. 本症例は額骨の厷籍な破壤，埋伏齿および退樎エ ナメル上皮との密接な関係，盾的細胞の多形性および增 磌形態などより，齿原性上皮に由来したものと考えられ た.

4. 本症例は術前照射 $(2,500 \mathrm{rads} / 10$ 回) 後, 左側全 项部疤清術および下額連続離断術が行われ，術後 2 年経 沉た現在，特に異常は認められず健在である。

5. 現在までに報告されている小児口腔癌腫症例に, 本例を加党た21例について検討した結果では，小児口腔

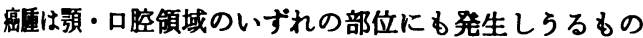
であが，特に舌，下頻に好発する傾向がるられた，下 预隍生ずる場合は成人の癌重とは異なり額骨中心性に生 ず恢度が高いままた，他領域の小児悪性腫痀に比べ て比較的年長児に好発する傾向がみられた。

\section{引用文 献}

1) 平山雄: 予防ガン学1977. 新宿書房, 東京, 1977, 118頁.

2）財団法人がんの子供を守る会，小児要性新生物 全国登䟿委員会：小児要性新生物 全 国 登錄一 1974年成楮. 日本医師会誌 75：1285 1976.

3）塙嘉之：小児の覀性尰瘄。第 1 版, 医学書 完, 東京, 1973，1頁

4）西鳮克巳，他：小児の悪性尰瘦。界展望 43: 5381974.

5）上野 正：小児の口腔外科的疾患。日本歯科医 師会誌 18: 31965 .

6) Gaisford, J.C.: Symposium on cancer of the head and neck. vol 2, Mosby Co, St Louis, 1969, p 162.

7) Dehner, L. P.: Tumors of the mandible and maxilla in children I. Cancer 31: 3641973.

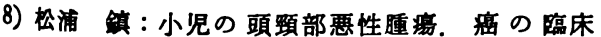
14: 7501968

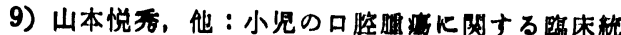
部的研究。日口外誌 24:83 1978.

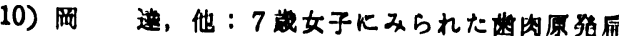
平上皮㨁症侧。口科誌 25：457 1976.

11) Aisenberg, M.S.: Malignant epithelial tumor of mandible in child aged 9. Am J Orthodont Oral Surg 28: 7361942.

12) Campelia, C.M., Boyle, P.E.: Embryonal carcinoma primary in the mandible of a child with involvement of tooth pulp. Am J Orthodont Oral Surg 292991943.

13) Kapiloff, B.: Squamous cell carcinoma in children. Plast Reconstr Surg 10: 501952.

14) Dowd, J.F.. A case of squamous cell carcinoma of the oral cavity in a ten year old boy. Plast Reconstr Surg 13: 1091954.

15) Merrifield, J.W., Dalitsch, W.W. and Steiner, M.: Epidermoid carcinoma of tongue and floor of mouth in infancy and childhood. Am J Dis Child 89: 2811955.

16) Stiebitz, R.. Zentrale Kieferkarzinome bei Kindern und Jugendlichen. Deutsche Zahn-, Mund-und Kieferheilkunde 40: 1091963.

17) Jones, J.H.: Soft Tissue Oral Tumours in Children: Their Structure, Histogenesis and Behaviour. Proc R Soc Med 59: 51966.

18) Lancaster, L., Fournet, L.F.: Carcinoma of a tongue in a child; Report of case. J Oral Surg 27: 2691969.

19) Turner, H., Snitzer, J.: Carcinoma of the tongue in a child. Oral Surg 37: 6631974.

20) Caldwell, R.D., Morrow, L. and Gold, L.: Carcinoma of the maxillary antrum in an 8year-old child. Part 1, Part 2. J Oral Surg 32: 278, 3671974.

21）作田正券，他：自然治寃した小児瘦の1例。瘦 の監床 21：296 1975.

22) 石川梧朗, 秋吉正患 : 口腔病理学 II. 改装版, 永末書店, 京都, 1970.1010頁。

23) Gorlin, R.J., Goldman, H.M.: Thoma's Oral Pathology II. ed 6, Mosby Co, St Louis, 1970, p 846.

24) Lucas, R.B.: Pathology of Tumours of the oral tissues. ed 2 , Churchill Livingstone, Edinfugh \& London, 1972, p 137.

25）尾崎登喜雄, 他 : 口腔転移癌（腺癌）の 2 例並 びに文献的考察。口科誌 27：173 1978.

26) Morrison, R., Deeley, T.J.: Intra-alveolar carcinoma of the jaw treatment by supervoltage radiotherapy Br J Radiol 35: 3211962.

27) Pindborg, J.J., Kramer, J. R.. Histological Typing of Odontogenic Tumours, Jaw Cysts, and Allied lesions. International Histological Classification of Tumours No 5. Geneva, Switzerland, WHO, 1971. 
28) Looser, K.G., Kuehn, P.G.: Primary tumor of the mandible. A Sudy of 49 cases. Am J Surg 132: 608: 1976.

29) Noran, R., Wood, K.N.: Central Squamous cell carcinoma of the mandible. $J$ Oral Surg 34: 2601976.

30) Shear, M.: Primary intra-alveolar epidermoid carcinoma of the jaw. J Pathol 97: 6451968.

31) De Lathouwer, C., Verhest, A.: Malignant primary intraosseous carcinoma of the mandible. Oral Surg 37: 771974.

32) Sirsat, M.V., et al.: Primary intra-alveolar squamous-cell carcinoma of the mandible: Report of case. Oral Surg 35: 3651973.

33) Eversole, L.R., Sabes, W.R. and Rovin, S.: Aggressive growth and neoplastic potential of odontogenic cysts. Cancer 35: 2701975.

34) Bhaskar, S. N.: Central mucoepidermoid tumors of the mandible; Report of cases.
Cancer 16: 7311963.

35) Brawand, B.C., et al.: Central mucoepideroid tumors of the jaws. Oral Surg 40: 631 1975.

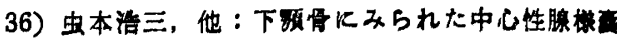

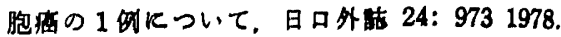

37) Gorlin, R.J., Goldman, H.M.: Thoma's Oral Pathology I. ed 6, Mosby Co, St Louis, 1970. p 451, 846.

38) Bradfield, W.J., Broadway, E.S.: Malignant change in a dentigerous cyst. $\mathrm{Br} \mathrm{J}$ Surg 45: 6571958.

39) Banerjee, S.C.: Squamous-cell carcinoma in a maxillary cyst. Oral Surg 23: 1931967.

40) Gardner, A.F.: The odontogenic cyst as a potential carcinoma: a clinicopathologic appraisal. J Am Dent assoc 78: 7461969.

41) Lapin, R., et al.: Squamous cell carcinoma arising in a dentigerous cyst. J Oral Surg 31: 3541973. 


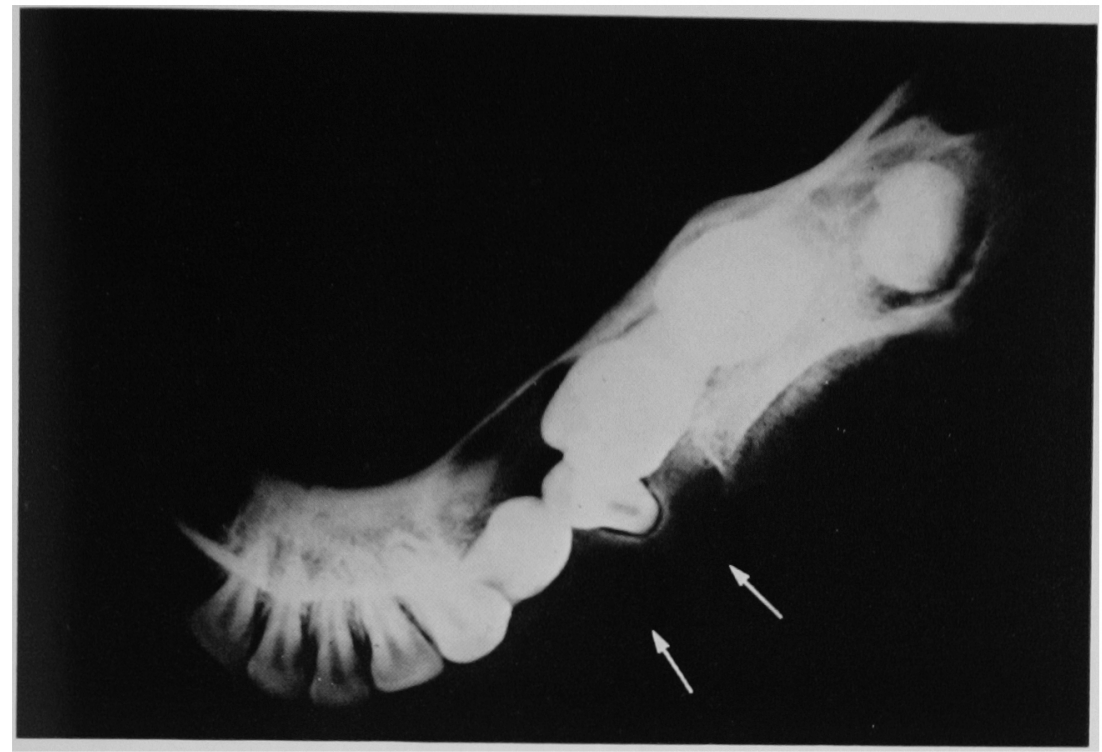

写重 7 摘出物 Softex 所見

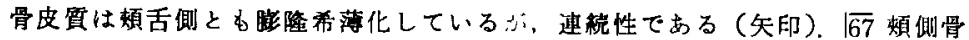
皮賈に故射状骨新生が諗められる。

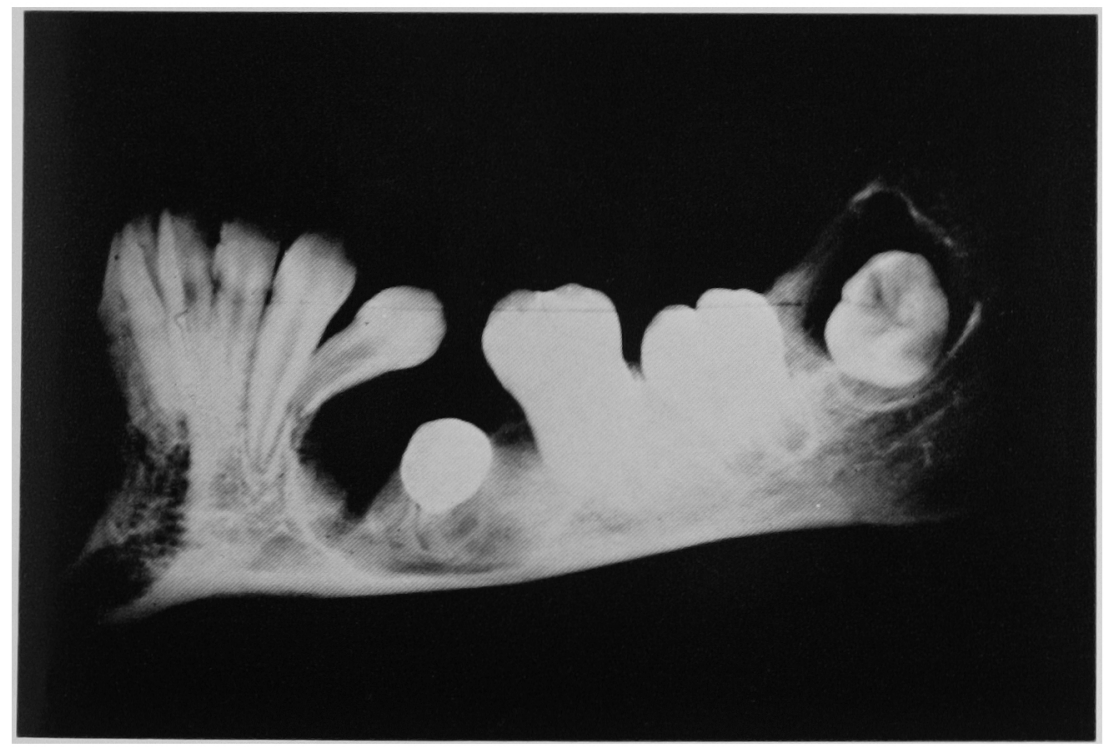

写真 8 同上 


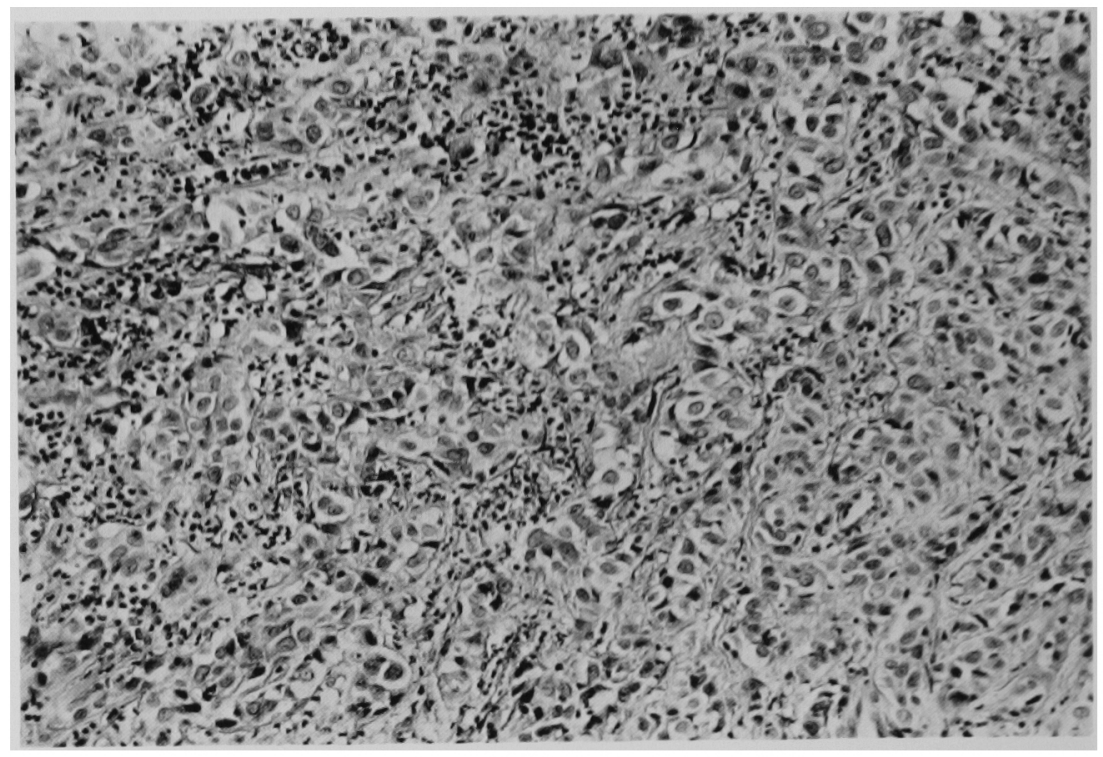

写真 $9 \sqrt{5}$ 部煩側因肉部からの生模標本

比較的大きな核と淡明な稩胞質をむつ腫境細胞が，小胞栄を作って充実性に增 殖している，角化の㑯向ははとんど示していない，間筫には多数の好酸球が認め られる。(H-E, ×

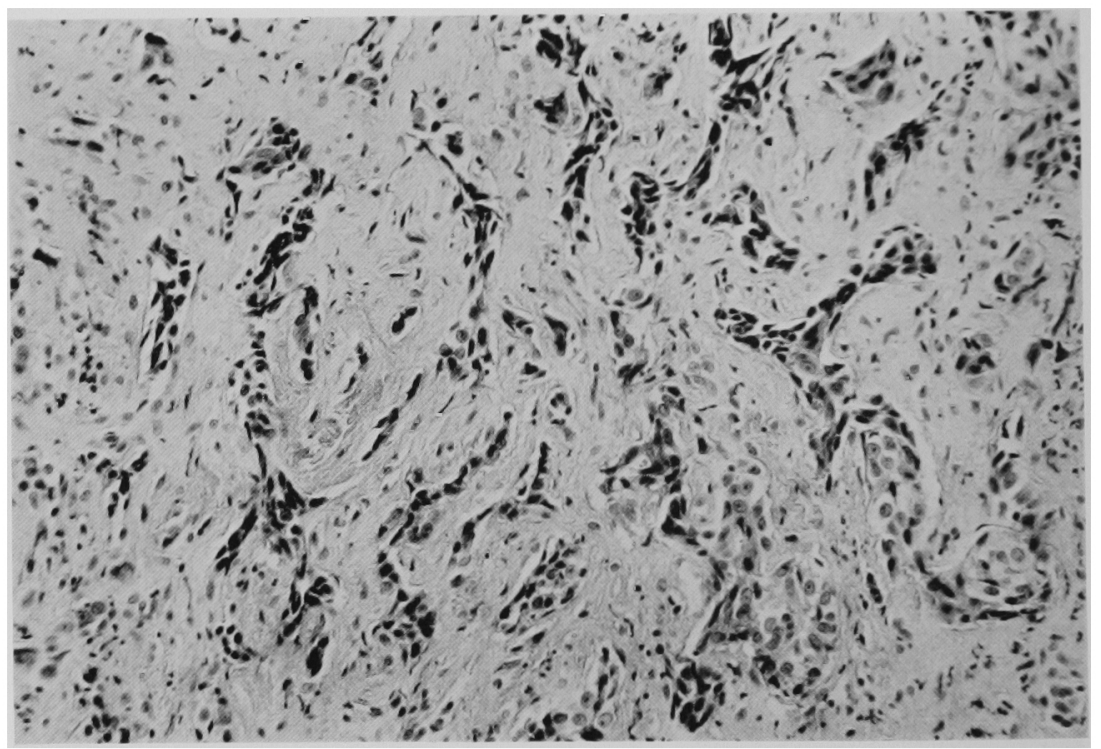

写真 $10 \mid \overline{5}$ 部頛側茵肉部から生検標本

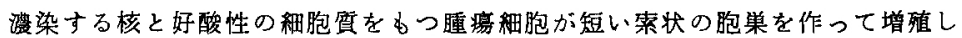
ている。比較的緻密な線維性組織よりなる多量の間質がみられる.(H-E， × 170) 


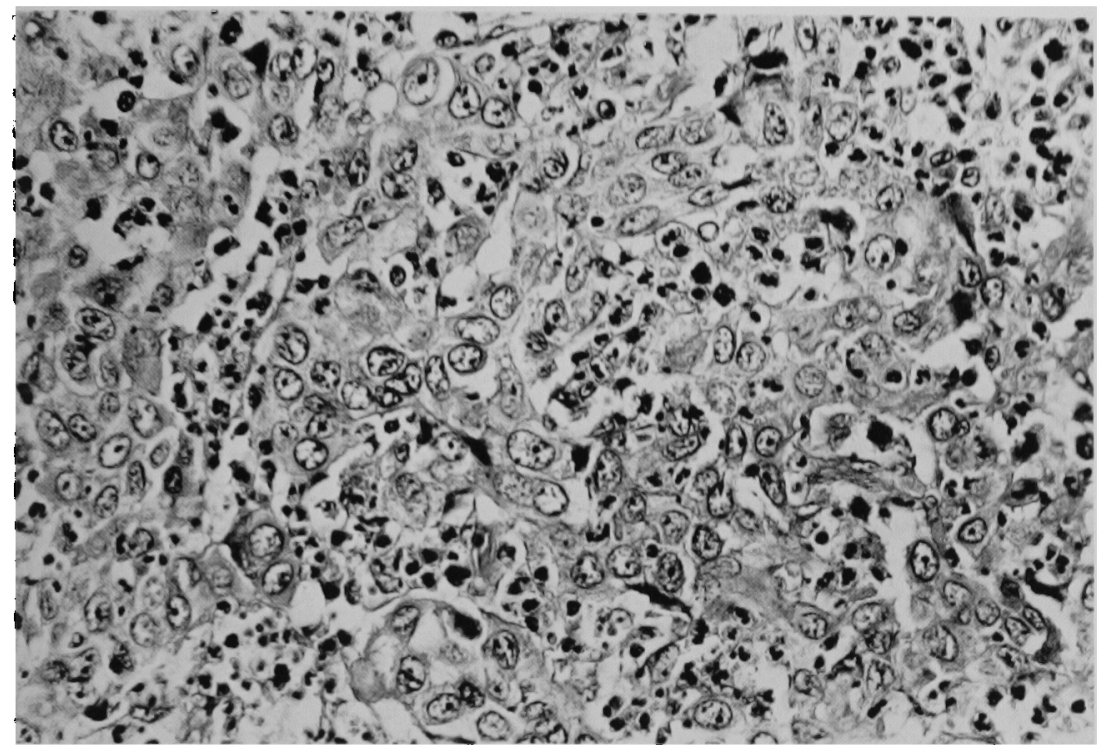

写直 11 リンパ節転移果の生検標本

異型性の比较的著明な腫富梱胞が充实性に增殖している，間質には多数の好酸 球が訯められる。(H-E, ×340)

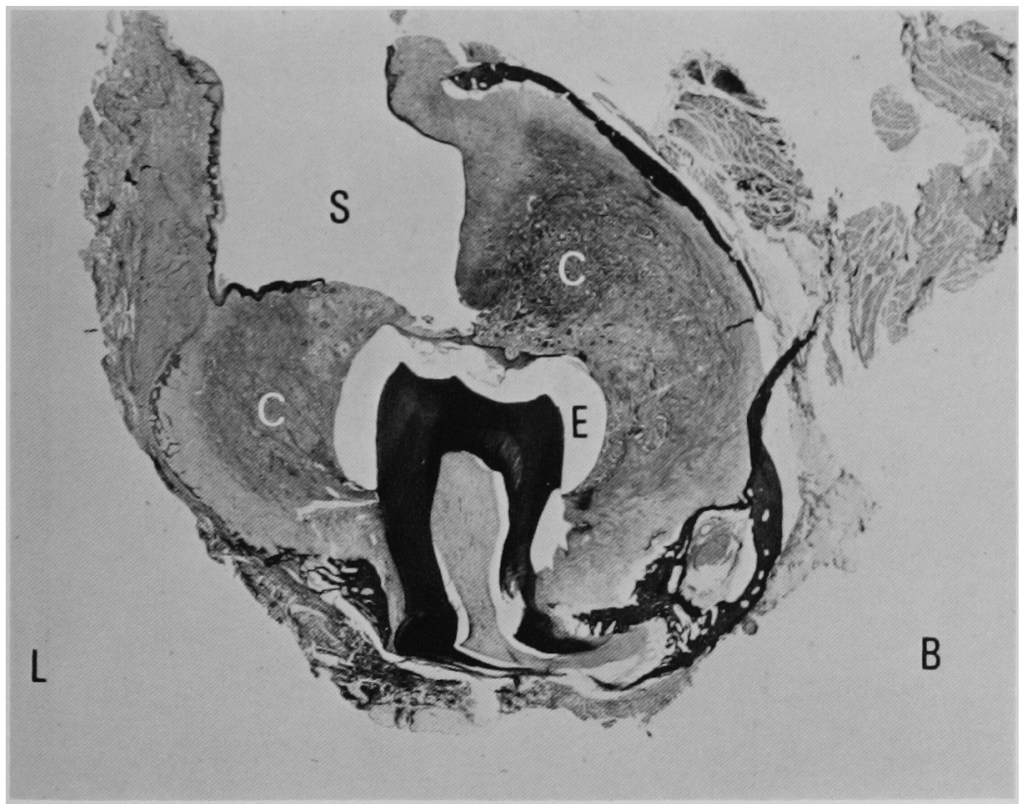

写直 12 手術標本， $\overline{5}$ を通る煩舌的断面

可は根尖部で煩側へ届曲しているが，冠部はほほ正常の形態を示している. 癌組織（C）は主として迷冠周囲に增殖している。(H-E，×3.3)

$\mathrm{E}$ ：脱灰により溶出したェナ^ル質の空隙 $\mathrm{S}: \mid \overline{\mathrm{E}}$ の菌槽に一致する陥凹部 


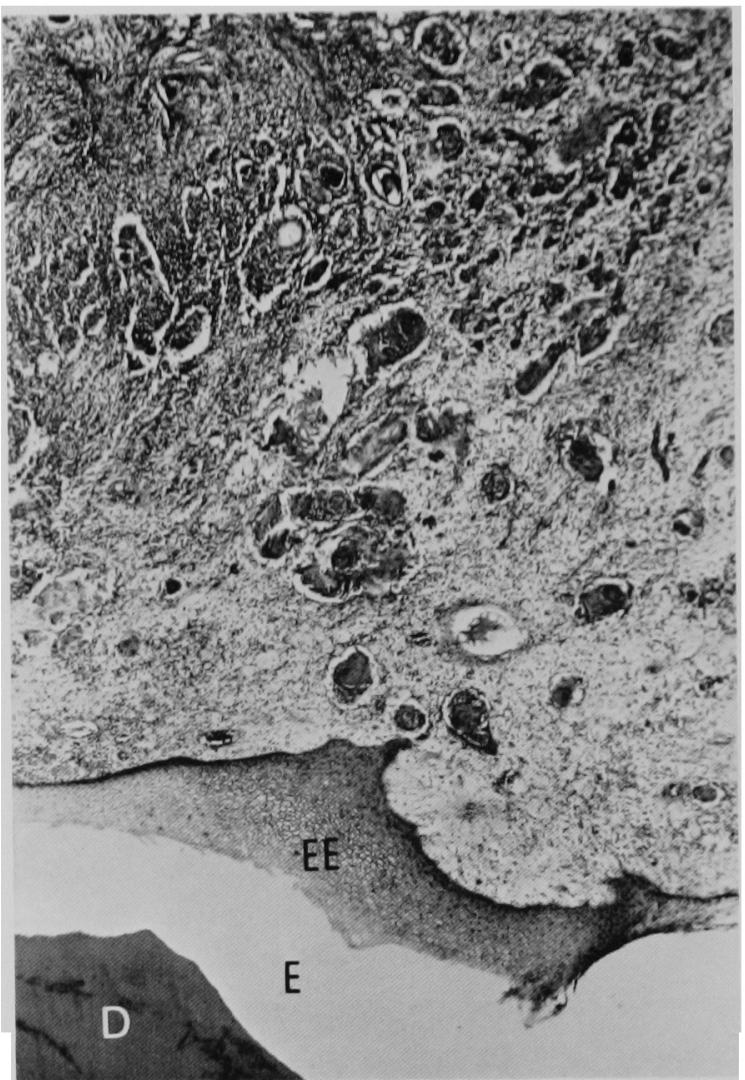

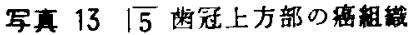

びまん性に一部汢小胞宩を作って增故して いる. (H-E, $\times 34)$

$\mathrm{EE}$ ：口䅝粘膜上皮と合して盵厚した䢙 縮エナイル上皮 $\mathrm{D}$ : 象牙質 $\mathrm{E}:$ エ イル質の空隙

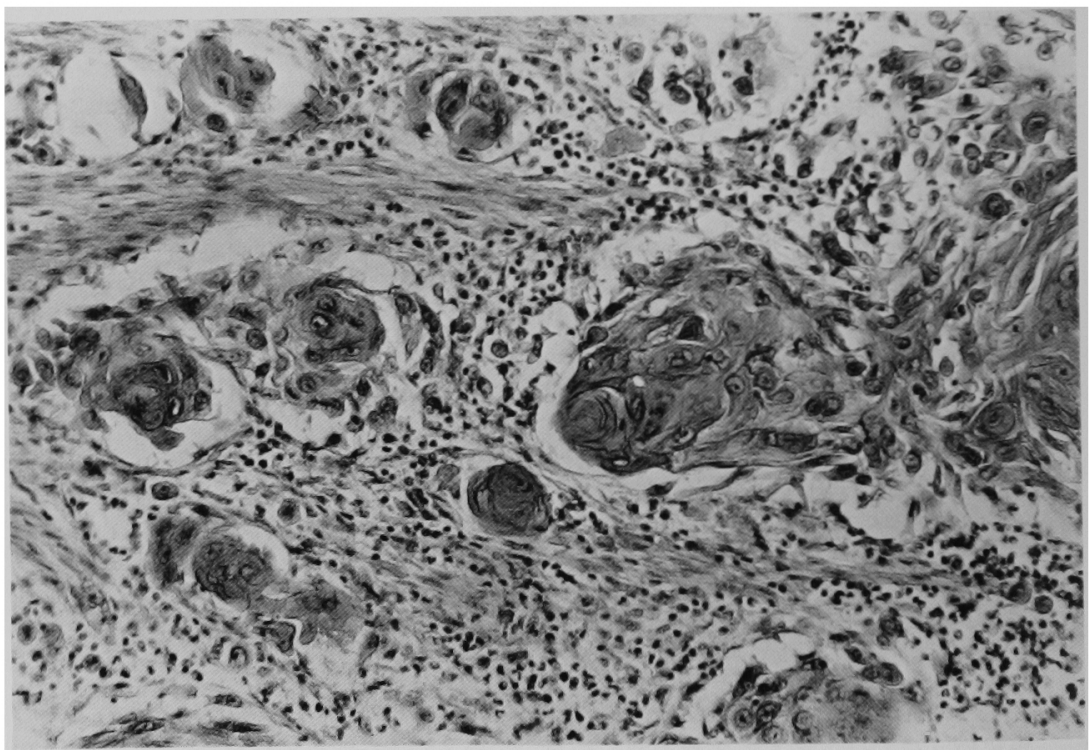

写直 $14 \mid \overline{5}$ 画冠上方部の癌租䪭

癌真珠様を呈する小胞宩を形成している，間質には好酸球の浸瀾が認められる. $(\mathrm{H}-\mathrm{E}, \quad \times 170)$ 


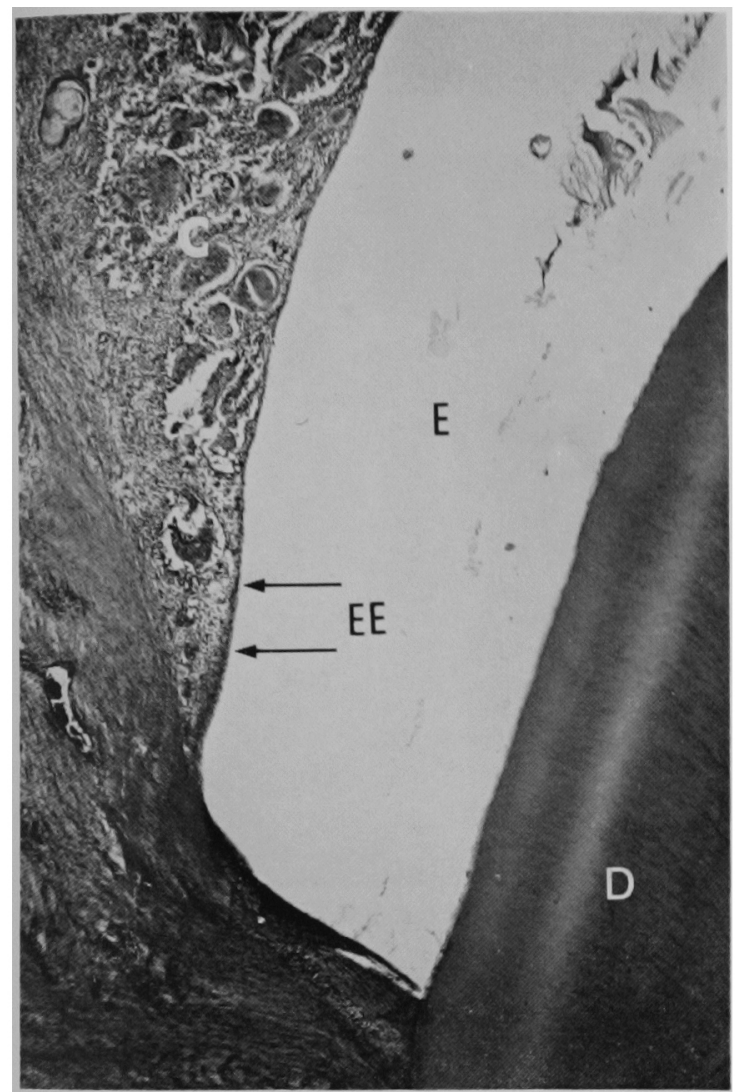

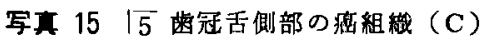
退樎エナィル上皮（EE 矢印）と窑に接し ている（H-E， ×34)
$\mathrm{D}$ : 象牙質
$\mathrm{E} ：$ メナメル質の空隙

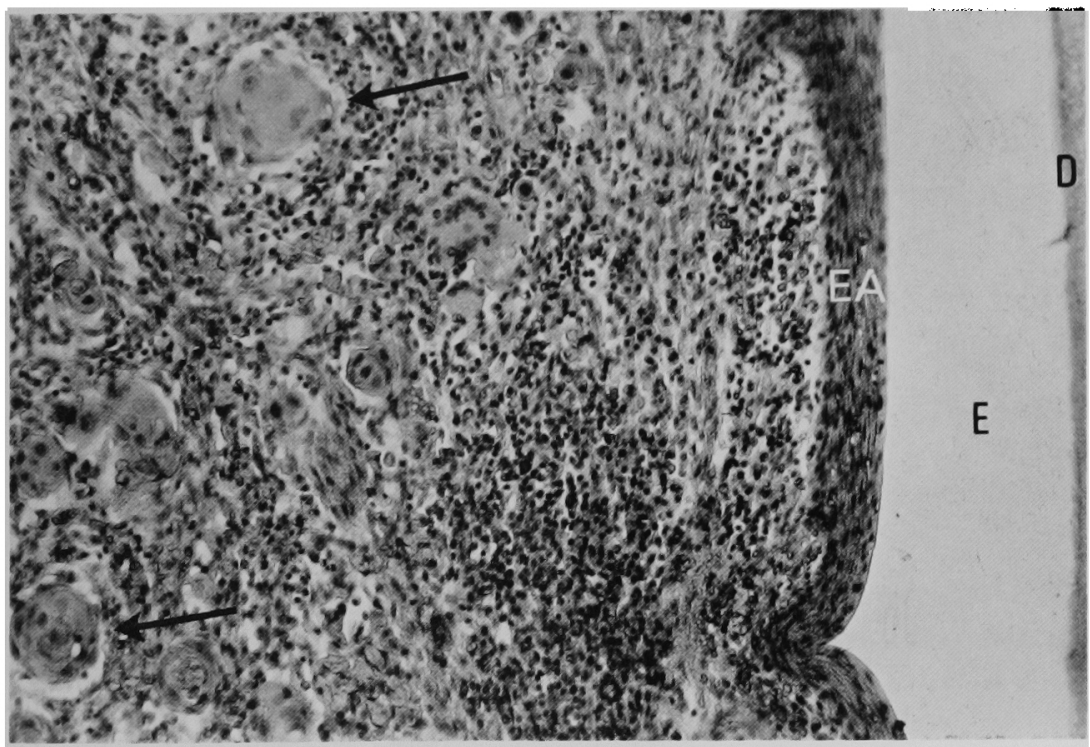

写真 $16 \mid \overline{4}$ 歯肉への浸潤

小さな癌胞巣を作って增殖している(矢印)，間質には好酸球を含む㷋症性細 胞漫潤がみられる。(H-E，×170)
$\mathrm{D}$ ：象牙質
$\mathrm{E}$ : ェナルル質の空隙
EA：上皮付着 


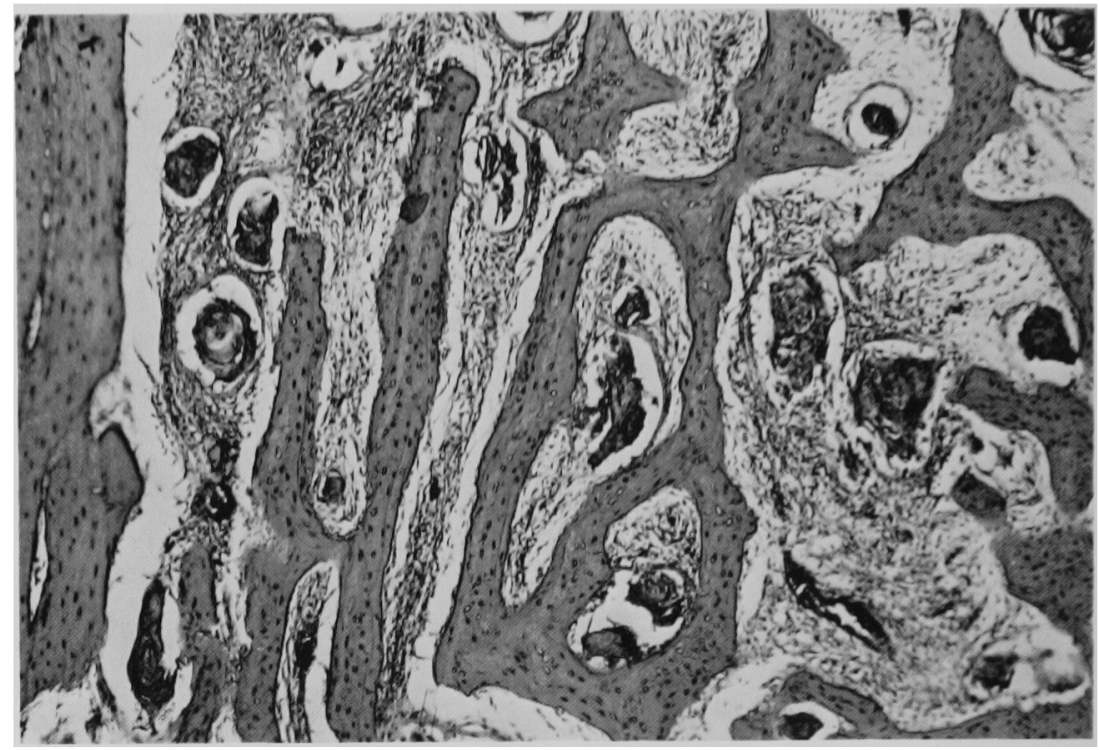

写真 $1 7 \longdiv { 7 }$ 部舌側の外骨膜性骨新生と新生骨内の癌胞巣 $(H-E, \times 68)$

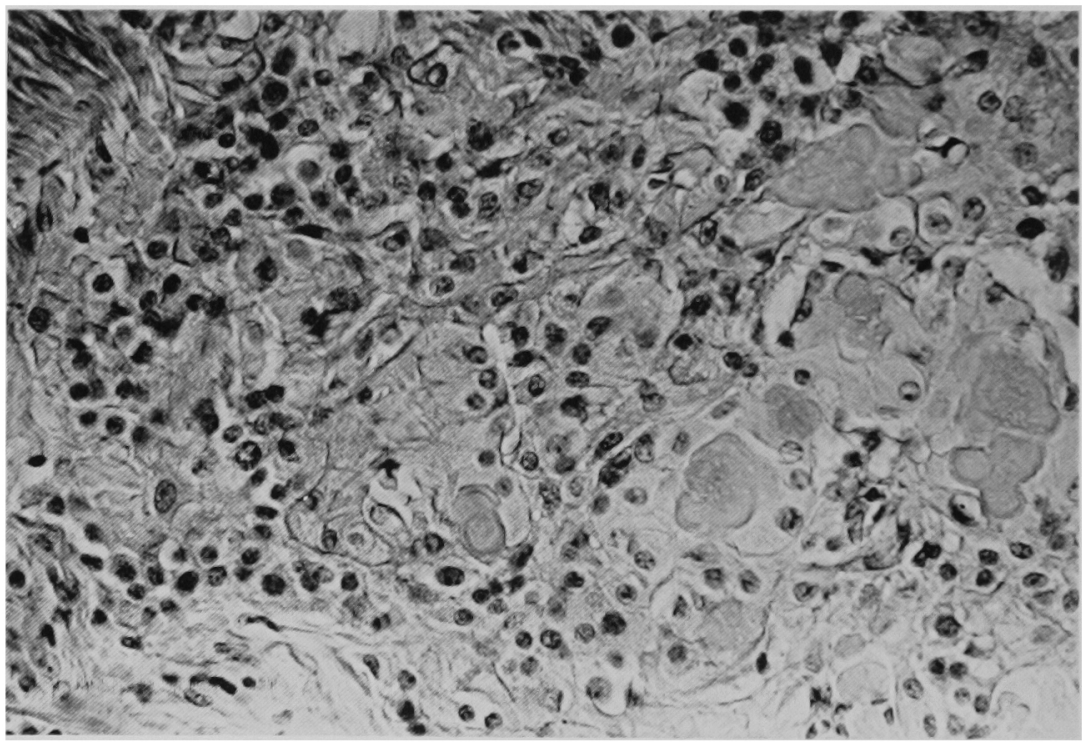

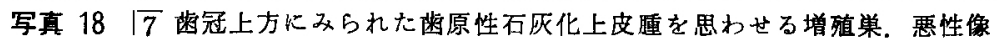
はみられない，(H-E， ×340) 